\title{
TINDAK TUTUR ILOKUSI DALAM UPACARA ADAT PERKAWINAN MASYARAKAT MUNA SULAWESI TENGGARA (Studi Penelitian Etnografi Komunikasi)
}

\author{
Ita Meiarni \\ Universitas Negeri Jakarta \\ itameiarni29@gmail.com
}

\begin{abstract}
Abstrak
Penelitian ini bertujuan untuk memperoleh pemahaman yang mendalam tentang tindak tutur ilokusi dalam upacara adat perkawinan masyarakat Muna di Desa Wali, Kecamatan Watopute, Kabupaten Muna, Sulawesi Tenggara. Pendekatan yang digunakan dalam penelitian ini adalah pendekatan kualitatif dengan metode etnografi komunikasi berdasarkan teori Hymes. Data penelitian ini adalah tuturan dalam bahasa Muna yang terjadi dalam prosesi upacara adat perkawinan masyarakat Muna yang mencakup data tindak tutur ilokusi representatif, direktif, komisif, ekspresif, dan deklaratif. Hasil dalam penelitian ini menunjukkan bahwa dalam upacara adat perkawinan masyarakat Muna ditemukan data tindak tutur ilokusi representatif berupa tindak tutur ilokusi representatif menyatakan, melaporkan, dan mengklaim. Data tindak tutur ilokusi direktif berupa tindak tutur ilokusi direktif perintah, memohon/meminta, berdoa, dan bertanya. Data tindak tutur ilokusi komisif berupa tindak tutur ilokusi komisif berjanji. Data tindak tutur ilokusi ekspresif berupa tindak tutur ilokusi ekspresif meminta maaf, memberi salam, dan menyampaikan rasa hormat. Data tindak tutur ilokusi deklaratif berupa tindak tutur ilokusi deklaratif penamaan dan menikahkan.
\end{abstract}

Kata kunci: tindak tutur, ilokusi, etnografi komunikasi

\begin{abstract}
The purpose of this research is to discover the deep comprehension about illocutionary speech act in the traditional wedding ceremony in Wali village, Watopute subdistrict, Muna regency, Southeast Sulawesi. The approach of the research is qualitative with ethnography communication methods based on Hymes theory. The data of the research are the speech is Muna language happened in the wedding ceremony. All the data taken included representatives illocutionary speech act, directives, commissives, expressives, and declaratives. The result of the study found in the wedding ceremony that stated, reported, and claimed as the data of representatives illocutionary speech acts; command, begging/asking, praying, and questioning as the data of directives illocutionary speech acts; promising as the data of commissive illocutionary speech acts; apologizing, greeting, and showing respect as the data of expressives illocutionary speech acts; giving a name and marriage as the data of declaratives illocutionary speech acts for found in the wedding ceremony of Muna society.
\end{abstract}

Keywords: speech acts, illocutionary, ethnography communication

\section{PENDAHULUAN}

Bahasa merupakan alat komunikasi yang digunakan oleh manusia untuk menyampaikan maksud atau informasi kepada manusia lain. Penggunaan bahasa dalam berkomunikasi tentunya tidak lepas dari konteks pembicaraan yang dilakukan atau biasa disebut dengan pengguna-an bahasa yang baik dan benar.
Fungsi bahasa tersebut juga terdapat dalam bahasa daerah yang digunakan oleh masyarakat di seluruh Indonesia. Salah satunya adalah Sulawesi Tenggara. Sulawesi Tenggara merupakan salah satu provinsi di Indonesia yang memiliki pendu-duk majemuk dan beragam etnis. Kemajemukan dan keberagaman etnis masyarakatnya menjadikan 
wilayah ini kaya dengan adat istiadat dan budaya, seperti bahasa dan upacara adat.

Salah satu etnis yang ada di Sulawesi Tenggara adalah etnis $\mathrm{Mu}$ na. Etnis Muna terdapat di kabupaten Muna dengan ibukota Raha. Etnis Muna memiliki warisan kebudayaan yang unik dan beragam. Salah satunya adalah upacara adat perkawinan dalam suku Muna. Upacara adat perkawinan merupakan upacara adat tradisional, yang berarti bahwa upacara adat tradisional merupakan kelakuan atau tindakan simbolis manusia sehubungan dengan kepercayaan yang mempunyai maksud dan tujuan.

Perkawinan merupakan salah satu kebudayaan yang dianggap sakral oleh masyarakat Muna. Dalam bahasa Muna, kata kawin diserap menjadi kata kawi. Bahasa asli bahasa Muna menyebutkan kata kawin disebut dengan gaa. Gaa artinya kawin. Sesuai tradisi adat perkawinan masyarakat Muna, jika hendak melaksanakan upacara adat perkawinan, orang tua kedua calon mempelai mengundang orang-orang yang bertugas dalam upacara adat tersebut. Tokoh-tokoh inilah yang terlibat dalam percakapan. Dalam percakapan tersebut, terjadi komunikasi dengan menggunakan bahasa daerah, yaitu bahasa Muna. Namun, bahasa yang digunakan penutur dalam upacara adat ini adalah baha-sa adat, bukan bahasa Muna yang biasa digunakan dalam percakapan seharihari.

Komunikasi yang terjadi antara tokoh-tokoh yang terlibat dalam upacara adat perkawinan tersebut tentunya menghasilkan tuturantuturan berupa kalimat-kalimat. Dalam bidang pragmatik, bahasa yang digunakan mengandung makna yang dipahami antara penutur dan mitra tutur. Salah satu hal yang berkaitan dengan bidang pragmatik tersebut adalah tindak tutur.

Tindak tutur merupakan kegiatan seseorang menggunakan bahasa kepada mitra tutur dalam rangka mengomunikasikan sesuatu. Makna yang dikomunikasikan tidak hanya dapat dipahami berdasarkan penggunaan bahasa dalam bertutur saja, tetapi juga ditentukan oleh aspekaspek komunikasi secara komprehensif, termasuk aspek-aspek situasional komunikasi. Tarigan (2009: 37) mengemukakan bahwa pengetahuan mengenai tindak tutur sangat penting bagi pengajaran bahasa, pengajaran pragmatik pada khususnya. Apabila dipakai dalam konteks, maka suatu ucapan tidak hanya mengandung makna alamiah atau makan proposional, tetapi mengandung makna sebagai suatu tindak tutur.

Teori tindak tutur (speech act) awalnya diperkenalkan oleh J.L. Austin, seorang guru besar di Universitas Harvard pada tahun 1956. Teori yang berasal dari materi kuliah ini selanjutnya dibukukan oleh J.O. Urmson (1965) dengan judul How to do Thing with Word? Namun, teori tersebut baru terkenal dalam studi linguistik setelah Searle (1969) menerbitkan buku berjudul Speech Act and Essay in The Philosophy of Language (Chaer dan Agustina, 2010:50).

Austin (1962:108) mengidentifikasi jenis-jenis tindakan yang dilakukan ketika berbahasa, yaitu lokusi, ilokusi, dan perlokusi. Tindak ilokusi menurut Austin (1962:150151) diklasifikasikan menjadi Verdi- 
citives, exercitives, commissives, behabitives, dan expositives. Selanjutnya, klasifikasi tindak tutur menurut Searle (1999:12-17), yaitu asertif 'assertives', direktif 'directive', komisif 'commissives', ekspresif 'expressives', dan deklarasi ' $\mathrm{dec}$ laration'. Hal ini sejalan dengan pandangan Yule (1996:53-54) dan Leech (1996:105-106).

Dalam penelitian ini, teori Austin tidak digunakan karena dalam teori Austin, terdapat ketidakjelasan antara tindakan ilokusi dan verba ilokusi. Jadi, teori yang akan dijadikan acuan dalam menganalisis yang sesuai dengan fokus dan subfokus penelitian adalah klasifikasi tindak ilokusi menurut Searle. Kalsifikasi tindak ilokusi menurut Searle adalah representatif atau asertif 'assertives', direktif 'directive', komisif 'commissives', ekspresif 'expressives', dan deklarasi 'declaration'.

Dalam pelaksanaan upacara adat masyarakat Muna, antara pihak mempelai laki-laki dan pihak mempelai perempuan melakukan komunikasi yang disertai dengan tindakan selanjutnya. Peristiwa tersebut dalam kajian pragmatik dinamakan tindak tutur, yang meliputi lokusi, ilokusi, dan perlokusi.

Lokusi dianggap tidak terlalu penting dalam sebuah tuturan karena hanya semata-mata merupakan pernyataan. Hal yang menjadi inti dari sebuah tuturan adalah tindak ilokusi karena tindak ilokusi merupakan tindak tutur yang mengandung makna pernyataan yang dituturkan oleh penutur, sedangkan, perlokusi merupakan kesesuaian respon yang diberikan lawan tutur terhadap maksud yang disampaikan penutur.
Berdasarkan uraian tersebut, peneliti ingin melakukan penelitian dengan judul "Tindak Tutur Ilokusi dalam Upacara Adat Perkawinan Masyarakat Muna Sulawesi Tenggara" yang diklasifikasikan menjadi tindak tutur ilokusi representatif, direktif, komisif, ekspresif, dan deklaratif.

\section{METODE}

Penelitian ini merupakan penelitian yang menggunakan pendekatan kualitatif dengan maksud mengumpulkan data, mengolah data, menganalisis data, dan menyajikan data secara objektif mengenai tindak tutur ilokusi dalam upacara adat perkawinan masyarakat Muna, Sulawesi Tenggara. Tindak tutur ilokusi ini akan diperoleh data dari proses upacara adat perkawinan masyarakat Muna yang ditinjau dari klasifikasi tindak ilokusi menurut Searle dengan metode etnografi komunikasi berdasarkan teori Hymes (1972:59-65).

Data penelitian ini adalah tuturan dalam bahasa Muna yang terjadi dalam prosesi upacara adat perkawinan masyarakat Muna. Sumber data penelitian ini adalah proses upacara adat masyarakat Muna, masyarakat Muna yang terlibat dalam prosesi upacara adat perkawinan masyarakat Muna, Sulawesi Tenggara, dalam hal ini disebut sebagai informan, dan informasi tertulis yang berkaitan dengan upacara adat masyarakat Muna Sulawesi Tenggara. Pengumpulan data dilakukan dengan menggunakan peneliti sebagai instrumen penelitian atau instrumen kunci. Teknik pengumpulan data yang dilakukan terdiri atas pengamatan berperan serta, doku- 
mentasi, perekaman, catatan lapangan, dan wawancara. Langkah-langkah menganalisis data dilakukan dengan membuat kategori berdasarkan situsi komunikatif, peristiwa komunikatif, dan tindakan komunikatif (Hymes dalam Sumar-sono, 2012:319-321). Pemeriksaan keabsahan data dalam penelitian ini menggunakan beberapa teknik, yaitu peneliti terlibat langsung dalam penelitian sekaligus sebagai instrumen penelitian, ketelitian dan keselektifan peneliti, kecukupan teori, trianggulasi teori, dan pemeriksaan sejawat.

\section{HASIL DAN PEMBAHASAN}

Tindak tutur ilokusi yang ada dalam upacara adat perkawinan masyarakat Muna Sulawesi Tenggara berdasarkan hasil pengamatan selama berada di lokasi penelitian terungkap berbagai jenis tindak tutur ilokusi berupa representatif, direktif, komisif, ekspresif, dan deklaratif. Tindak tutur terjadi melalui interaksi antara pelaku adat pihak perempuan dan pelaku adat pihak laki-laki, antara sesama pelaku adat pihak perempuan, dan antara sesa-ma pelaku adat pihak laki-laki.

Tindak tutur ilokusi representatif merupakan bagian tindak tutur yang mengikat penuturnya kepada kebenaran yang dikatakannya. Penutur mengatakan dengan tegas sesuatu hal mengenai kebenaran proposisi yang diungkap. Dalam upacara adat ini, ditemukan tindak tutur ilokusi representatif berupa tindak tutur ilokusi representatif menyatakan, melaporkan, dan mengklaim. Salah satu contoh tuturan yang mengandung tindak tutur ilokusi representatif menyata-kan adalah sebagai berikut:

\section{"Paemo adumoli ingka"}

"Saya tidak akan ke sana lagi"

Tuturan pada contoh tersebut diungkapkan oleh utusan delegasi laki-laki yang menyatakan dirinya tidak akan kembali bersama rombongan yang belum berada di tempat. Utusan delegasi ini melakukan tuturan karena perwakilan delegasi perempuan telah bertanya kepadanya. Dalam hal ini, utusan delegasi laki-laki telah menyatakan dirinya untuk duduk bersama delegasi perempuan sambil menunggu kedatangan rombongan delegasi lakilaki yang sesaat lagi akan sampai ke tempat pelaksanaan upacara perkawinan.

Tindak tutur ilokusi representatif melaporkan dalam upacara adat perkawinan masyarakat Muna Sulawesi Tenggara digunakan oleh pelaku adat pihak laki-laki dan pelaku adat pihak perempuan. Namun, yang lebih cenderung meng-gunakan tindak tutur ilokusi ini adalah pelaku adat pihak laki-laki. Salah satu contoh tuturan yang mengandung tindak tutur ilokusi representatif melaporkan adalah sebagai berikut:

"Aitu ingka padamo tafetapa we sumbali ne anahi bhe neinano anahi, ingka minaho bhe tumungguno kambakamba we karete watu, aitu intaidimo sotumungguno."

"Kami sudah memperoleh jawaban dari anak gadis dan ibunya, bunga-bunga di halaman belum ada penjaganya 
dan sekarang anak tuanlah yang akan menjaganya."

Dalam tuturan tersebut mengandung pernyataan berupa melaporkan orang yang akan menjaga, merawat, dan menyirami bunga yang ditanam pertama kali di halaman setiap pagi.

Selanjutnya, tindak tutur ilokusi representatif mengklaim dalam upacara adat perkawinan masyarakat Muna Sulawesi Tenggara digunakan oleh pelaku adat pihak perempuan. Contoh tuturan yang mengandung tindak tutur ilokusi representtatif mengklaim adalah sebagai berikut:

"Aitu ingka padamo tafetapa we sumbali ne anahi bhe neinano anahi, ingka minaho bhe tumungguno kambakamba we karete watu, aitu intaidimo sotumungguno."

"Kami sudah memperoleh jawaban dari anak gadis dan ibunya, bunga-bunga di halaman belum ada penjaganya dan sekarang anak tuanlah yang akan menjaganya."

Tanggapan pelaku adat pihak perempuan tersebut yang mengatakan bahwa anak tuanlah yang akan menjaganya menunjukkan tindak tutur ilokusi representantif "mengklaim".

Tindak tutur ilokusi direktif merupakan tindak tutur yang digunakan pembicara agar pendengar melakukan sesuatu. Tindak tutur ilokusi direktif dalam upacara adat perkawinan masyarakat Muna berupa tuturan yang digunakan oleh pelaku adat pihak laki-laki dan pelaku adat pihak perempuan yang dimaksudkan agar lawan tutur melakukan sesuatu tindakan. Tuturan tersebut berupa tindak tutur ilokusi direktif perintah, memohon/meminta, berdoa, dan bertanya.

Tindak tutur ilokusi direktif perintah dalam upacara adat perkawinan masyarakat Muna Sulawesi Tenggara digunakan oleh pelaku adat pihak laki-laki dan pelaku adat pihak perempuan dengan menggunakan kata "silahkan". Dalam upacara adat ini, tindak tutur ilokusi direktif perintah lebih banyak digunakan oleh pelaku adat pihak perempuan. Salah satu contoh tuturan yang mengandung tindak tutur ilokusi direktif perintah adalah sebagai berikut:

"Ingka tapandehanemo nagha, damansurumo te songino anahi nagha"

"Kami sudah mengetahui maksud ibu-ibu, silahkan langsung ke kamar calon pengantin perempuan"

Tuturan pada contoh tersebut diungkapkan oleh pelaku adat perempuan pihak perempuan yang dimak-sudkan untuk memberikan jawaban bahwa mereka mempersilahkan pelaku adat perempuan pihak laki-laki memasuki kamar pengantin perempuan untuk memulai prosesi peminangan. Dengan demikian, tuturan pelaku adat pihak perempuan tersebut termasuk kategori tindak tutur ilokusi direktif "perintah".

Tindak tutur ilokusi direktif memohon/meminta dalam upacara adat perkawinan masyarakat Muna 
Sulawesi Tenggara digunakan oleh pelaku adat pihak laki-laki dan pelaku adat pihak perempuan dengan menggunakan kata "memohon". Dalam upacara adat ini, tindak tutur ilokusi direktif memohon/meminta lebih banyak digunakan oleh pelaku adat pihak laki-laki. Salah satu contoh tuturan yang mengandung tindak tutur ilokusi direktif memohon/meminta adalah sebagai berikut:

"Assalamu alaikum, aesalo kalalesa, bhe kantalea, bhara nehamai sokafetapaha nasebantara itu?"

"Assalamualaikum, saya mohon keikhlasan dan perkenan, kiranya saya diberi petunjuk, kira-kira untuk memulai awal pekbicaraan adat kepada siapa kita menghadap?"

Dalam tuturan tersebut pihak laki-laki membuka prosesi dengan memohon keikhlasan dan perkenan dari keluarga perempuan agar diberi petunjuk mengenai siapa pelaku adat yang akan dihadapi untuk memulai pembicaraan adat.

Tindak tutur ilokusi direktif berdoa dalam upacara adat perkawinan masyarakat Muna Sulawesi Tenggara digunakan oleh pelaku adat pihak laki-laki dan pelaku adat pihak perempuan. Dalam upacara adat ini, kecenderungan penggunaan tindak tutur ilokusi direktif berdoa oleh pelaku adat pihak laki-laki dan pelaku adat pihak perempuan sama. Salah satu contoh tuturan yang mengandung tindak tutur ilokusi direktif berdoa adalah sebagai berikut:
"Pedahae itu, ingka tapandehanemo nagha kabholosino patudhu mani. Tesaloane maafu welo ngkora-ngkora ini tabhotusiemo deki ampa naini, naefua namintae itu maka tamai tora taempalimpali behambaku. Sio-siomo daeghawa kaghosa bhe katolala ne kasimie-miehano Allah Taala"

"Hari ini, kami sudah mengetahui jawaban dari maksud kedatangan kami. Untuk itu, kami mohon maaf, pertemuan ini kami cukupkan sampai di sini dan kami akan datang kembali ke sini dua hari setelah besok. Mudah-mudahan kita semua mendapat limpahan kesehatan dan kesempatan dari Allah SWT"

Pada tuturan tersebut, pihak laki-laki memohon maaf untuk undur diri dari rumah keluarga perempuan sekaligus memanjatkan doa kepada Allah SWT agar semuanya dilimpahkan kesehatan dan kesempatan untuk bertemu kembali pada dua hari setelah besok.

Tindak tutur ilokusi direktif bertanya dalam upacara adat perkawinan masyarakat Muna Sulawesi Tenggara digunakan oleh pelaku adat pihak laki-laki dan pelaku adat pihak perempuan. Dalam upacara adat ini, tindak tutur ilokusi direktif bertanya lebih banyak digunakan oleh pelaku adat pihak laki-laki. Salah satu contoh tuturan yang mengandung tindak tutur ilokusi direktif bertanya adalah sebagai berikut: 
"Walaikumsalam, ingka dokorato-ratom dua watu fointagino, minamo bhe niwawangi, bhara nando dasumowo itu?"

"Walaikumsalam yang akan menunggu kedatangan tuantuan sudah tiba semua, apakah tuan-tuan masih mau ke sana?"

Tuturan pada contoh tersebut diungkapkan oleh perwakilan delegasi perempuan yang menanyakan apakah utusan delegasi laki-laki masih akan kembali ke rombongan delegasi laki-laki atau akan menetap bersama delegasi perempuan.

Tindak tutur ilokusi komisif merupakan tindak tutur yang digunakan oleh pembicara untuk melakukan sesuatu pada masa yang akan datang. Tindak tutur ilokusi komisif dalam upacara adat perkawinan masyarakat Muna berupa tuturan-tuturan yang dituturkan oleh pelaku adat pihak laki-laki dan pelaku adat pihak perempuan yang digunakan untuk berkomitmen atau berjanji pada sesuatu hal yang akan dilakukan pada masa yang akan datang. Penggunaan tindak tutur iloku-si komisif berjanji dalam upacara adat pekawinan masyarakat Muna Sula-wesi Tenggara yang digunakan oleh pelaku adat pihak laki-laki dan pelaku adat pihak perempuan memiliki kecenderungan yang sama. Salah satu contoh tuturan yang mengandung tindak tutur ilokusi komisif berjanji adalah sebagai berikut:

"Walaikumsalam. Aitu ingka tapandehanemo nagha patu- dhuntoomu, naefua namintae itu tamantagida"

"Walaikusalam. Sekarang kami sudah mengetahui maksud kedatangan tuan-tuan, dua hari setelah besok kami akan tung-gu kedatangan mereka"

Pada tutran tersebut, keluarga pihak perempuan berjanji akan menunggu kedatangan keluarga lakilaki pada waktu yang telah ditentukan.

Tindak tutur ilokusi ekspresif merupakan suatu tindak tutur yang menyatakan keadaan psikologis secara tulus tentang keadaan tertentu. Tindak tutur ilokusi ekspresif dalam upacara adat perkawinan masyarakat Muna berupa tindak tutur ilokusi ekspresif meminta maaf, memberi salam, dan menyampaikan rasa hormat.

Tindak tutur ilokusi ekspresif meminta maaf dalam upacara adat perkawinan masyarakat Muna Sulawesi Tenggara digunakan oleh pelaku adat pihak laki-laki dan pelaku adat pihak perempuan dengan menggunakan kata "maaf". Contoh tuturan yang mengandung tindak tutur ilokusi ekspresif meminta maaf adalah sebagai berikut:

"Pedahae itu, ingka tapandehanemo nagha kabholosino patudhu mani. Tesaloane maafu welo ngkora-ngkora ini tabhotusiemo deki ampa naini, naefua namintae itu maka tamai tora taempalimpali behambaku. Sio-siomo daeghawa kaghosa bhe katolala ne kasimie-miehano Allah Taala" 
"Hari ini, kami sudah mengetahui jawaban dari maksud kedatangan kami. Untuk itu, kami mohon maaf, pertemuan ini kami cukupkan sampai di sini dan kami akan datang kembali ke sini dua hari setelah besok. Mudah-mudahan kita semua mendapat limpahan kesehatan dan kesempatan dari Allah SWT"

Pada tuturan tersebut terlihat bahwa pihak laki-laki memohon maaf untuk undur diri dari rumah pihak perempuan, sehingga dikate-gorikan ke dalam tindak tutur ilokusi ekspresif meminta maaf.

Tindak tutur ilokusi ekspresif memberi salam dalam upacara adat perkawinan masyarakat Muna Sulawesi Tenggara digunakan oleh pelaku adat pihak laki-laki. Salah satu contoh tuturan yang mengan-dung tindak tutur ilokusi ekspresif memberi salam adalah sebagai berikut:

"Assalamu alaikum. Ingka aratoghoomo katudundo kamokulahi ini, ampaitu we kundomo watu andoa"

"Assalamualaikum. Kedatangan saya kemari diutus oleh orang-orang tua, sekarang mereka telah berada di belakang (sesaat lagi akan sampai di tempat pelaksanaan upacara perkawinan)"

Utusan delegasi laki-laki dalam tuturannya mengucapkan salam assalamu alaikum sebelum memulai pembicaraan. Dengan demikian, tuturan tersebut juga termasuk dalam kategori tindak tutur ilokusi ekspresif "memberi salam".

Tindak tutur ilokusi ekspresif menyampaikan rasa hormat dalam upacara adat perkawinan masyarakat Muna Sulawesi Tenggara digunakan oleh pelaku adat pihak perempuan. Contoh tuturan yang mengandung tindak tutur ilokusi ekspresif menyampaikan rasa hormat adalah sebagai berikut:

"Aini padamo toadhati kasamiimu, aitu tamadhati kaetamu dua"

"Sekarang tuan-tuan sudah menghormati kami, kami akan memberikan penghormatan adat kepada tuan-tuan"

Dalam tuturannya, pelaku adat pihak perempuan menyampaikan bahwa mereka akan menyerahkan uang matano kenta sebagai bentuk penyampaian rasa hormat kepada pihak laki-laki karena pihak laki-laki telah memberi penghormatan kepada pihak perempuan dalam adat.

Tindak tutur ilokusi deklaratif merupakan karakteristik yang berkait-an dengan kesuksesan kinerja mengenai bentuk, isi proposal, dan realitas. Tindak tutur ilokusi deklaratif dalam upacara adat perkawinan masyarakat Muna berupa tindak tutur ilokusi deklaratif penamaan dan tindak tutur ilokusi deklaratif menikahkan.Tindak tutur ilokusi deklaratif penamaan dalam upacara adat perkawinan masyarakat Muna Sulawesi Tenggara digunakan oleh pelaku adat pihak laki-laki. Contoh tuturan yang mengandung tindak 
tutur ilokusi deklaratif penamaan adalah sebagai berikut:

"Nimaighoo mani ini neano a Rahmat anamoghane La Fani. Kambea nekansiloghono mata mani ini ingka kambea netisa kedua"

"Nama laki-laki yang kami maksud untuk menjaga bunga tersebut adalah Rahmat, putra dari bapak La Fani. Bunga yang menarik perhatian kami adalah bunga yang ditanam kedua"

Dalam tuturan tersebut, pelaku adat pihak laki-laki menyebutkan nama anak laki-laki yang akan menjaga, merawat, dan menyirami bunga yang ditanam kedua di halaman setiap pagi. Dengan demikian, tuturan tersebut menunjukkan tindak tutur ilokusi deklarasi "penamaan".

Tindak tutur ilokusi deklaratif menikahkan dalam upacara adat perkawinan masyarakat Muna Sulawesi Tenggara digunakan oleh kepala KUA/penghulu dalam meni-kahkan kedua mempelai. Contoh tuturan yang mengandung tindak tutur ilokusi deklaratif menikahkan adalah sebagai berikut:

\footnotetext{
"Bismillahirrahmanirrahim, gholeitu ini awalighoo La Ode Agama dosakusiane ompulu ruafuluno, ihintu Rahmat bin La Fani amogaako bhe Wa Ode Sitti Musriani binti La Ode Agama, kaowano beano raafulu bhoka, sabhabuno Allah Ta'ala"
}

"Bismillahirrahmanirrahim, pada hari ini saya bertindak sebagai wali atas permintaan Bapak La Ode Agama disaksikan oleh seluruh keluarga besar, saya akan menikahkan Saudara Rahmat bin La Fani dengan perempuan yang bernama Wa Ode Sitti Musriani binti La Ode Agama dengan mas kawin 20 BM karena Allah Ta'ala"

Tuturan pada contoh tersebut diungkapkan oleh penghulu dalam upacara adat perkawinan. Dalam tuturannya, penghulu bermaksud menikahkan kedua mempelai dalam bentuk pernyataan yang ditujukan kepada calon pengantin laki-laki yang disaksikan oleh keluarga kedua belah pihak.

\section{SIMPULAN}

Berdasarkan hasil penelitian, ditemukan sebanyak 31 data tindak tutur ilokusi representatif yang terdiri atas 13 data tindak tutur ilokusi representatif menyatakan, 17 data tindak tutur ilokusi representatif melaporkan, dan 1 tindak tutur ilokusi representatif mengklaim. Tindak tutur ilokusi representatif dalam upacara adat perkawinan masyarakat Muna berupa tuturan yang diucapkan oleh pelaku adat pihak laki-laki, pelaku adat pihak perempuan, calon pengantin perem-puan, kepala KUA/ penghulu, dan calon pengantin lakilaki tanpa ada keragu-raguan karena telah diyakini kebenarannya.

Tindak tutur tutur ilokusi direktif ditemukan sebanyak 31 data yang terdiri atas 3 data tindak tutur ilokusi direktif perintah, 18 data tindak tutur ilokusi direktif memohon/ 
meminta, 2 data tindak tutur ilokusi direktif berdoa, dan 8 data tindak tutur ilokusi direktif bertanya. Tindak tutur ilokusi direktif dalam upacara adat perkawinan masyarakat Muna berupa tuturan yang digunakan oleh pelaku adat pihak laki-laki dan pelaku adat pihak perempuan yang dimaksudkan agar lawan tutur melakukan sesuatu tindakan.

Tindak tutur ilokusi komisif ditemukan sebanyak 4 data yang merupakan tindak tutur ilokusi komisif berjanji. Tindak tutur ilokusi komisif dalam upacara adat perkawinan masyarakat Muna berupa tuturan-tuturan yang dituturkan oleh pelaku adat pihak laki-laki dan pelaku adat pihak perempuan yang digunakan untuk berkomitmen atau berjanji pada sesuatu hal yang akan dilakukan pada masa yang akan datang. Penggunaan tindak tutur ilokusi komisif berjanji dalam upacara adat pekawinan masyarakat Muna Sulawesi Tenggara yang diguna-kan oleh pelaku adat pihak laki-laki dan pelaku adat pihak perempuan memiliki kecenderungan yang sama.

Tindak tutur ilokusi ekspresif ditemukan sebanyak 7 data yang terdiri atas 3 data tindak tutur ilokusi ekspresif meminta maaf, 5 data tindak tutur ilokusi ekspresif memberi salam, dan 1 data tindak tutur ilokusi ekspresif menyam-paikan rasa hormat. Tindak tutur ilokusi ekspresif dalam upacara adat perkawinan masyarakat Muna berupa tuturantuturan pelaku dat pihak laki-laki dan pelaku adat pihak perempu-an yang menyatakan suatu keadaan psikologis secara tulus tentang keadaan tertentu.

Tindak tutur ilokusi deklaratif ditemukan sebanyak 2 data yang terdiri atas 1 data tindak tutur ilokusi deklaratif penamaan dan 1 data tindak tutur ilokusi deklaratif menikahkan. Tindak tutur ilokusi deklaratif dalam upacara adat perkawinan masyarakat Muna berupa tuturan pelaku adat pihak laki-laki dan kepala KUA/ penghulu yang dilakukan untuk menciptakan status dan keadaan sebagai sesuatu yang baru.

\section{REFERENSI}

Alwasilah, A. Chaedar. Pengantar Sosiolinguistik Bahasa. Bandung: Angkasa. 1993.

Aslinda dan Leni Syafyahya. Pengantar Sosiolinguistik. Bandung: Refika Aditama. 2010.

Chaer, Abdul dan Leoni Agustin. Sosiolinguistik Pengenalan Awal. Jakarta: Rineka Cipta. 1995.

Emzir. Metodologi Penelitian Pendidikan: Kuantitatif dan Kualitatif. Jakarta: PT Raja Grafindo Persada. 2012.

Fasold, Ralph W. An Introduction to language and linguistics. New York: Cambridge University Press. 2006.

Griffith, Patrick. An Introduction to English Semantics and Pragmatics. Edinburgh: Edinburgh University Press. 2006.

Hymes, Dell. "Models of the Interaction of language and Social Life" dalam Direction in Sociolinguistics The Ethnogtaphy of Communication, (Ed.) by John J. Gumperz dan Dell Hymes. USA: Hold, Rinehart and Winston. 1972.

Foundations in Sociolinguistics: An Ethnographic Approach. 
USA: University of Pennsylvania Press, Inc. 1985. Jaszczolt, K.M. Semantics and Pragmatics Meaning in Language and Discourse. London: Pearson Education. 2002.

Kridalaksana. Harimurti. Kamus Linguistik. Jakarta: PT Gramedia.1982.

Leech, Geofrey. Principle of Pragmatics. New York: Longman Group Ltd. 1996.

Maulid. Tradisi Lisan Kagaa dalam Masyarakat Muna di Sulawesi Tenggara, Perubahan dan Keberlanjutannya. Tesis, Universitas Indonesia.2012.

Parera, J.D. Teori Semantik. Jakarta: Erlangga. 2004.

Rahardi, Kunjana. Sosiopragmatik. Jakarta : Erlangga.2009.

Reimer, Nick. Introducing Semantics. Cambridge: Cambridge University Press. 2010.

Sadock, Jerrold. "Speech Acts" dalam The Handbook Pragmatics (ed.) Laurence R. Horndan Gregory Ward. Oxford: Blackwell Publishing. 2006.

Sapri, Andi. Makna Simbolik pada Tata Cara Perkawinan Angkamata Masyarakat Muna. Kendari Pos: Edisi Minggu 16 November 2014.

Schiffrin, Deborah. Approaches to Discourse. Oxford UK \& Cambridge USA: Blackwell. 1994.

Searle, John R. Speech Acts: An Essay in The Philosophy of Language. Cambridge: Cambridge University Press. 1969.

Meaning Studies in the Theory of Speech Acts.Cambridge: Cambridge University Press. 1999.

Sumarsono.

Sosolinguistik.

Yogyakarta: SABDA. 2012.

Tarigan, Henry Guntur. Pengajaran

Pragmatik.

Angkasa:

Bandung. 2009.

Yule, George. Pragmatics. New York: Oxford University Press. 1996.

Zegarac, Vladimir dan Martha C. Pennington. "Pragmatic Transfer" dalam Culturally Speaking: Culture, Communication and Politeness Theory (ed.) Helen Spencer-Oatey. New York: Continuum. 2000. 
BAHTERA: Jurnal Pendidikan Bahasa dan Sastra, Volume 16 Nomor 1 Januari 2017 http://journal.unj.ac.id/unj/index.php/bahtera/ ISSN : 0853-2710 